\title{
GC-MS Analysis of Ethanol Extract of Taxithelium napalense (Schwaerg) Broth along with its $\alpha$-Glucosidase Inhibitory Activity
}

\author{
V. B. TATIPAMULA ${ }^{1 *}$, K. N. KILLARI, K. V. GOPAIAH ${ }^{1}$ AND ALEKHYA KETHA \\ Pharmaceutical Chemistry Department, AU College of Pharmaceutical Sciences, Andhra University, Visakhapatnam-530 003, \\ ${ }^{1} \mathrm{~K}$ L College of Pharmacy, Koneru Lakshmaiah Education Foundation, Vaddeswaram, Guntur-522 502, India
}

Tatipamula et al.: GC-MS analysis of Taxithelium napalense

\begin{abstract}
Considering the antidiabetic potentiality of the moss Taxithelium napalense, the present study was undertaken to explore the chemical constituents that are present in this species. The entire moss Taxithelium napalense was extracted by ethanol and the extract obtained was subjected to gas chromatography-mass spectrometry. Sixty nine compounds were identified, which are reported for the first time from this species. From the gas chromatography-mass spectrometry analysis, it was determined that the octadecanoic acid methyl ester was the chief component present in Taxithelium napalense. In addition, the total phenolic and flavonoid contents of ethanol extract of Taxithelium napalense were found to be $101.43 \pm 0.38 \mathrm{mg} \mathrm{Q} / \mathrm{g}$ and $229.73 \pm 3.07$ mg GA/g, respectively. Additionally, the $\mathrm{IC}_{50}$ of the ethanol extract of Taxithelium napalense on $\alpha$-glucosidase was found to be $34.5 \mu \mathrm{g} / \mathrm{ml}$, while acarbose value was $29.5 \mu \mathrm{g} / \mathrm{ml}$. This is the first report on the chemical investigation of the moss Taxithelium napalense.
\end{abstract}

Key words: Moss, chemical constituents, gas chromatography, mass spectroscopy, metabolites

Mosses are non-vascular plants with rhizoids. They are grouped into the division of Bryophyte under the subdivision Musci. About 17000 species of moss falling in 89 families and ca. 898 genera are distributed across the world and in India, about 1786 moss species are recorded till now ${ }^{[1]}$. Generally, mosses are habituated in wet environments such as alpine and rainforest ecosystems, in addition, mosses require fresh water to their reproduction ${ }^{[1,2]}$. Due to their unique habitat, they are scrutinized for biological evaluations because of their nutritional contents ${ }^{[2]}$, for instance, Sphagnum palustre moss has renoprotective effects ${ }^{[3]}$ and aromatase inhibitory activity ${ }^{[4]}$.

Taxithelium napalense (Schwaerg) Broth, family Sematophyllaceae is an epiphytic moss. T. napalense is habituated on twigs and branches of other plants in semi evergreen forests found in palaeotropical region $^{[5]}$. Earlier, the phytochemical, antioxidant and in vivo antidiabetic potential of the ethanol extract of T. napalense was reported ${ }^{[6]}$. In the present study, it was aimed to identify the active metabolites present in this moss using gas chromatography-mass spectrometry (GC-MS) analysis. Additionally, the total flavonoid and phenolic contents along with its $\alpha$-glucosidase inhibitory activity was also determined.
The specimens of Taxithelium nepalense (Schwaerg) Broth was collected from barks of mangrove, Rhizophora species from Bhitarkanika island (2072' N latitude and $86^{\circ} 87^{\prime}$ E Longitude) Orissa, India in March 2016. The moss T. nepalense was authenticated in the Council of Scientific and Industrial Research (CSIR)-National Botanical Research Institute (NBRI), Lucknow and deposited at Bryophyte Herbarium, CSIR-NBRI, Lucknow, India with an accession number LWG-5/VB-Orissa-2016 ${ }^{[1]}$.

The moss specimens collected from the mangrove plants were shade-dried. The dried lichen material was powdered using a blender and about $12 \mathrm{~g}$ of moss material was exhaustively extracted thrice with ethanol at room temperature. The mixture was filtered through muslin cloth and evaporated under reduced pressure to obtain ethanol extract $(1.21 \mathrm{~g}, 10.08 \% \mathrm{w} / \mathrm{w})$ as a dark greenish solid, which were stored in amber colored vials and preserved at $4^{\circ}$ till further use.

This is an open access article distributed under the terms of the Creative Commons Attribution-NonCommercial-ShareAlike 3.0 License, which allows others to remix, tweak, and build upon the work non-commercially, as long as the author is credited and the new creations are licensed under the identical terms

Accepted 27 April 2019

Revised 28 December 2018

Received 29 October 2018

Indian J Pharm Sci 2019;81(3):569-574 
All the chemicals and reagents used in the present study were of analytical grade. $p$-nitrophenyl- $\alpha$-Dglucopyranoside, rat intestinal acetone powder, sucrose and acarbose, were procured from Sigma-Aldrich (Mumbai, India). Glibenclamide was purchased from Aventis Pharma Ltd. (Mumbai, India).

The phytochemical investigation of ethanol extract of T. nepalense was performed on GC-MS equipment (GCMS-QP2010 Plus, Shimadzu, Europe). Experimental parameters of GC-MS system were, column oven temperature: $50^{\circ}$, injection temperature: $250^{\circ}$, injection mode: split; flow control mode: linear velocity; pressure: $29.7 \mathrm{kPa}$; total flow: $10.9 \mathrm{ml} / \mathrm{min}$; column flow: $0.72 \mathrm{ml} / \mathrm{min}$; linear velocity: $30.7 \mathrm{~cm} / \mathrm{s}$; purge flow: $3.0 \mathrm{ml} / \mathrm{min}$; split ratio: 10.0 . Oven temperature program was $50^{\circ}$ hold time for $2 \mathrm{~min}$, at $200^{\circ}$ hold time for $0 \mathrm{~min}$ and $280^{\circ}$ hold time for $2 \mathrm{~min}$. The GC program was ion-source temperate at $210^{\circ}$, interface temperature at $250^{\circ}$, solvent cut time: $3 \mathrm{~min}$, detector gain: $1.07 \mathrm{kV}+0.20 \mathrm{kV}$ and threshold of 1000 .

The total flavonoid content ${ }^{[7]}$ of the extracts were determined by using aluminium chloride spectrophotometric method, in which $\mathrm{AlCl}_{3}$ forms complex with hydroxyl groups of flavonoids exist in the testing sample. To the extract $(1 \mathrm{mg} / \mathrm{ml})$ or standard quercetin solution $(3.125,6.25,12.5,25,50$, $100 \mu \mathrm{g} / \mathrm{ml}$ ), added $3 \mathrm{ml}$ of methanol, $1 \mathrm{ml}$ of $2 \% \mathrm{AlCl}_{3}$ solution, $200 \mu \mathrm{l}$ of $1 \mathrm{M}$ potassium acetate and made up to $10 \mathrm{ml}$ with distilled water and incubated for $60 \mathrm{~min}$ at room temperature, whereas the blank contained only reagents and the absorbance was noted at $415 \mathrm{~nm}$. Based on the measured absorbance of the test sample, the total flavonoid content was read on the calibration curve and the total flavonoid content was expressed in terms of quercetin equivalent $(\mathrm{mg}$ of $\mathrm{Q} / \mathrm{g}$ of extract).

The total phenolic content ${ }^{[7]}$ was estimated by FolinCiocalteu's method. To the extract $(1 \mathrm{mg} / \mathrm{ml})$ or standard gallic acid solution $(3.125,6.25,12.5,25,50$, $100 \mu \mathrm{g} / \mathrm{ml}$ ), added $0.5 \mathrm{ml}$ of Folin-Ciocalteau reagent, $1.5 \mathrm{ml}$ of sodium carbonate $(20 \%)$ solution and volume made up to $10 \mathrm{ml}$ with distilled water and incubated at room temperature for $120 \mathrm{~min}$ and the absorbance was measured at $750 \mathrm{~nm}$ using spectrophotometer against blank (contained only reagents). Based on the measured absorbance of the test sample, the total phenolic content was read on the calibration curve and the total phenolic content was expressed in terms of gallic acid equivalent (mg of $\mathrm{GA} / \mathrm{g}$ of extract).
The assay of $\alpha$-glucosidase inhibitory activity was estimated using the method reported by Tatipamula et $a l .{ }^{[8]}$ in triplicate $(\mathrm{n}=3)$. Two microlitres of $\alpha$-glucosidase from rat intestine acetone powder solution (a stock solution of $1.0 \mathrm{mg} / \mathrm{ml}$ in $10 \mathrm{mM}$ phosphate buffer, $\mathrm{pH}$ 6.8, diluted 40-fold with phosphate buffer) was mixed with $20 \mu 1$ of the samples at different concentrations $(25,50,75$ and $100 \mu \mathrm{g} / \mathrm{ml}$ solubilized in dimethyl sulfoxide) to which $100 \mu 1$ of $50 \mathrm{mM}$ phosphate buffer ( $\mathrm{pH} 6.8$ ) was added in a 96 well microtitre plate and incubated for $5 \mathrm{~min}$ at $37^{\circ}$. After incubation, $50 \mu \mathrm{l}$ of substrate $(5 \mathrm{mM}$ of $p$-nitrophenyl$\alpha$-D-glucopyranoside prepared in $50 \mathrm{mM}$ of phosphate buffer, $\mathrm{pH}$ 6.8) was added and the entire reaction mixture was again incubated for $20 \mathrm{~min}$ at $37^{\circ}$. Thereafter the reaction was terminated by adding $50 \mu \mathrm{l}$ of $\mathrm{Na}_{2} \mathrm{CO}_{3}$ ( $1 \mathrm{M})$ and the final volume was made up to $150 \mu 1$. The amount of $p$-nitrophenol released from substrate was noted at $405 \mathrm{~nm}$ spectrophotometrically (Spectra MAX plus 384, Molecular Devices Corporation, Sunnyvale, CA, USA). Dimethyl sulfoxide and acarbose were used as control and standard, respectively. Percent enzyme inhibition was calculated using the Eqn., percent inhibition $=(\mathrm{C}-\mathrm{S}) / \mathrm{C} \times 100$, where $\mathrm{C}$ is the absorbance of the control, $\mathrm{S}$ is the absorbance of sample. $\mathrm{IC}_{50}$ values of the samples were determined by plotting percent inhibition against concentrations.

After successful extraction of the whole moss material, the dried extract was subjected to GC-MS analysis. The GC-MS spectrum revealed the presence of various chemical components with different retention times (fig. 1), whereas the MS analyzes the compounds eluted at different times to detect its nature and structure of the compounds. The results pertaining to GC-MS analysis of the ethanol extract of $T$. nepalense lead to the identification of a number of compounds. The various compounds present in the entire stressed moss of ethanol extract of $T$. nepalense along with their retention time, molecular formula, molecular weight, peak area (\%) and nature of the compound that were detected by the GC-MS were represented in Table 1. A total of 69 compounds were identified by GC-MS analysis (Table 1). In addition, the composition determined for the ethanol extract of T. nepalense corresponds to $63.59 \%$ of the entire GC-MS chromatogram.

From the GC-MS analysis, it was observed that this moss species contained mostly aliphatic fatty acids and its derivatives. Therefore, the standard way for cells to synthesize fatty acids is through the fatty acid synthesis cycle as shown in fig. 2. This cycle of eight 


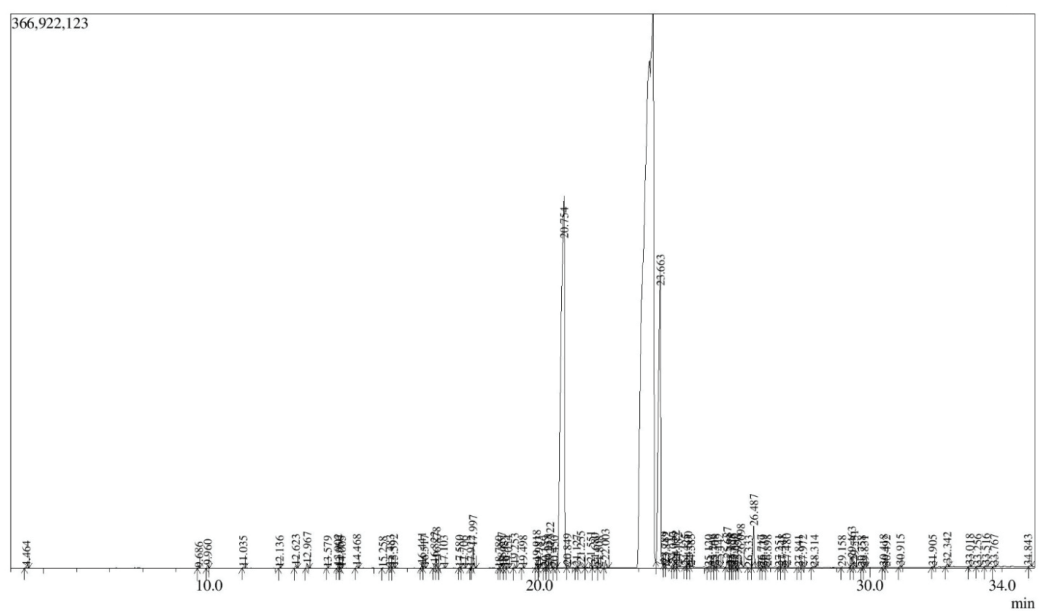

Fig. 1: GC-MS chromatogram of ethanol extract of T. nepalense

\section{TABLE 1: COMPOUNDS IDENTIFIED FROM GC-MS ANALYSIS OF THE ETHANOL EXTRACT OF} TAXITHELIUM NAPALENSE

\begin{tabular}{|c|c|c|c|c|c|}
\hline RT (min) & Name of the compound & $\begin{array}{c}\text { Molecular } \\
\text { formula }\end{array}$ & $\begin{array}{c}\text { Molecular } \\
\text { weight } \\
\text { (g/mol) }\end{array}$ & $\begin{array}{c}\text { Peak } \\
\text { area } \\
(\%)\end{array}$ & Nature of the compound \\
\hline 4.464 & Hexanal & $\mathrm{C}_{6} \mathrm{H}_{12} \mathrm{O}$ & 100.16 & 0.10 & Aliphatic aldehyde \\
\hline 9.686 & Nonanal & $\mathrm{C}_{9} \mathrm{H}_{18} \mathrm{O}$ & 142.24 & 0.02 & Aliphatic aldehyde \\
\hline 9.960 & Octanoic acid & $\mathrm{C}_{8} \mathrm{H}_{16} \mathrm{O}_{2}$ & 144.21 & 0.15 & Aliphatic carboxylic acid \\
\hline 11.035 & 1-Dodecene & $\mathrm{C}_{12} \mathrm{H}_{24}$ & 168.32 & 0.05 & Aliphatic alkene \\
\hline 12.136 & 2-Decenal & $\mathrm{C}_{10} \mathrm{H}_{18} \mathrm{O}$ & 154.25 & 0.03 & Aliphatic alkene \\
\hline 12.623 & (Z)-2,4-Decadienal & $\mathrm{C}_{10} \mathrm{H}_{16} \mathrm{O}$ & 152.24 & 0.13 & Aliphatic alkene \\
\hline 12.967 & $(\mathrm{E}, \mathrm{E})-2,4-$ Decadienal & $\mathrm{C}_{10} \mathrm{H}_{16} \mathrm{O}$ & 152.24 & 0.27 & Aliphatic alkene \\
\hline 13.579 & $(\mathrm{E}, \mathrm{E})$-2-Undecenal & $\mathrm{C}_{11} \mathrm{H}_{20} \mathrm{O}$ & 168.28 & 0.02 & Aliphatic alkene \\
\hline 13.902 & 1-Pentadecene & & 210.41 & 0.10 & Aliphatic alkene \\
\hline 13.950 & 2-Decanone & $\mathrm{C}_{10} \mathrm{H}_{20} \mathrm{O}$ & 156.27 & 0.01 & Aliphatic ketone \\
\hline 14.005 & Tetradecane & $\mathrm{C}_{14} \mathrm{H}_{30}$ & 198.39 & 0.03 & Aliphatic alkane \\
\hline 14.468 & Nonanoic acid & $\mathrm{C}_{9} \mathrm{H}_{18} \mathrm{O}_{2}$ & 158.24 & 0.13 & Aliphatic carboxylic acid \\
\hline 15.258 & 2-Tridecanone & $\mathrm{C}_{13} \mathrm{H}_{26} \mathrm{O}$ & 198.35 & 0.02 & Aliphatic ketone \\
\hline 16.441 & 1-Hexadecene & & 224.43 & 0.19 & Aliphatic alkene \\
\hline 16.517 & Hexadecane & $\mathrm{C}_{16} \mathrm{H}_{34}$ & 226.45 & 0.10 & Aliphatic alkane \\
\hline 16.878 & 4,5-Dimethoxy benzophenone & $\mathrm{C}_{15} \mathrm{H}_{14} \mathrm{O}_{4}$ & 258.27 & 0.50 & Aromatic ketone \\
\hline 17.580 & 2,4-Di-t-butyl-6-nitro-6-dodecanone & $\mathrm{C}_{20} \mathrm{H}_{40} \mathrm{NO}_{3}$ & 342.54 & 0.05 & Aliphatic ketone \\
\hline 17.922 & Hexadecanal & $\mathrm{C}_{16} \mathrm{H}_{32} \mathrm{O}$ & 240.43 & 0.03 & Aliphatic aldehyde \\
\hline 17.997 & Methyl tetradecanoate & $\mathrm{C}_{15} \mathrm{H}_{30} \mathrm{O}_{2}$ & 242.40 & 1.14 & Aliphatic ester \\
\hline 18.780 & Heptadecanoic acid & $\mathrm{C}_{17} \mathrm{H}_{34} \mathrm{O}_{2}$ & 270.46 & 0.02 & Fatty acid \\
\hline 18.857 & 16-Methyl-1-octadecene & $\mathrm{C}_{19} \mathrm{H}_{38}$ & 265.51 & 0.26 & Aliphatic alkene \\
\hline 18.933 & Heneicosane & $\mathrm{C}_{21} \mathrm{H}_{44}$ & 296.58 & 0.11 & Aliphatic alkane \\
\hline 19.054 & 5-Octadecenoic acid & $\mathrm{C}_{18} \mathrm{H}_{34} \mathrm{O}_{2}$ & 282.47 & 0.06 & Fatty acid \\
\hline 19.498 & Pentadecanoic acid & $\mathrm{C}_{15} \mathrm{H}_{30} \mathrm{O}_{2}$ & 242.40 & 0.17 & Fatty acid \\
\hline 19.918 & 2-Undecanone & $\mathrm{C}_{11} \mathrm{H}_{22} \mathrm{O}$ & 170.30 & 0.07 & Aliphatic ketone \\
\hline 19.983 & 6,10-Dimethyl-9-heptadecanone & $\mathrm{C}_{19} \mathrm{H}_{38} \mathrm{O}$ & 282.51 & 0.36 & Aliphatic ketone \\
\hline 20.159 & 10-Methyl-E-11-tridece-1-ol-acetate & $\mathrm{C}_{16} \mathrm{H}_{30} \mathrm{O}_{2}$ & 254.41 & 0.02 & Aliphatic ester \\
\hline 20.322 & 9-Hexadecenoic acid & $\mathrm{C}_{16} \mathrm{H}_{30} \mathrm{O}_{2}$ & 254.41 & 1.01 & Fatty acid \\
\hline 20.450 & 9-Hexadecenoic acid methyl ester & $\mathrm{C}_{16} \mathrm{H}_{30} \mathrm{O}_{2}$ & 268.44 & 0.05 & Aliphatic ester \\
\hline 20.754 & Octadecanoic acid methyl ester & $\mathrm{C}_{19} \mathrm{H}_{38} \mathrm{O}_{2}$ & 298.51 & 52.09 & Aliphatic ester \\
\hline 20.849 & 3-Hydroxy cyclodecene & $\mathrm{C}_{10} \mathrm{H}_{18} \mathrm{O}$ & 154.25 & 0.12 & Cyclic hydroxyl compound \\
\hline 21.680 & Cyclopropaneoctanoic acid & $\mathrm{C}_{11} \mathrm{H}_{20} \mathrm{O}_{2}$ & 184.28 & 0.28 & Fatty acid \\
\hline 22.003 & Heptadecanoic acid methyl ester & $\mathrm{C}_{18} \mathrm{H}_{36} \mathrm{O}_{2}$ & 248.48 & 0.50 & Aliphatic ester \\
\hline 23.789 & Methyl octadec-9-enoate & $\mathrm{C}_{19} \mathrm{H}_{36} \mathrm{O}_{2}$ & 297.487 & 0.11 & Aliphatic ester \\
\hline 23.842 & Methyl 9-cis,11-trans-octadecadienoate & $\mathrm{C}_{19} \mathrm{H}_{34} \mathrm{O}_{2}$ & 294.48 & 0.08 & Aliphatic ester \\
\hline
\end{tabular}




\begin{tabular}{|c|c|c|c|c|c|}
\hline 24.040 & Ethyl (9Z,12Z)-9,12-octadecadienoate & $\mathrm{C}_{20} \mathrm{H}_{36} \mathrm{O}_{2}$ & 308.51 & 0.18 & Aliphatic ester \\
\hline 24.122 & (E)-9-Octadecenoic acid ethyl ester & $\mathrm{C}_{20} \mathrm{H}_{38} \mathrm{O}_{2}$ & 310.52 & 0.40 & Aliphatic ester \\
\hline 24.425 & 9-Cis, 11 -trans-octadecadienoate-1-docosene & $\mathrm{C}_{18} \mathrm{H}_{32} \mathrm{O}_{2}$ & 280.45 & 0.07 & Fatty acid \\
\hline 25.246 & Behenic alcohol & $\mathrm{C}_{22}^{10} \mathrm{H}_{46} \mathrm{O}$ & 326.61 & 0.08 & Aliphatic hydroxyl compound \\
\hline 25.442 & $9,12,15$-Octadecatrienoic acid & $\mathrm{C}_{18} \mathrm{H}_{30} \mathrm{O}_{2}$ & 278.44 & 0.17 & Fatty acid \\
\hline 25.828 & $9,12,15$-Octadecatrienoic acid methyl ester & $\mathrm{C}_{19} \mathrm{H}_{32} \mathrm{O}_{2}$ & 292.46 & 0.11 & Aliphatic ester \\
\hline 25.890 & $6,9,12$-Octadecatrienoic acid & $\mathrm{C}_{18} \mathrm{H}_{30} \mathrm{O}_{2}$ & 278.44 & 0.11 & Fatty acid \\
\hline 25.996 & Oxiraneoctanoic acid 3-octyl-methyl ester & $\mathrm{C}_{19} \mathrm{H}_{36} \mathrm{O}_{3}$ & 312.49 & 0.11 & Aliphatic ester \\
\hline 26.098 & Cyclopropaneoctanoic acid methyl ester & $\mathrm{C}_{12} \mathrm{H}_{22} \mathrm{O}_{2}$ & 198.31 & 0.94 & Aliphatic ester \\
\hline 26.333 & 8-Hexadecenal & $\mathrm{C}_{16} \mathrm{H}_{30} \mathrm{O}$ & 238.42 & 0.04 & Aliphatic aldehyde \\
\hline 26.717 & $(9 \mathrm{E}, 12 \mathrm{E})-9,12$-Octadecadienoyl chloride & $\mathrm{C}_{18} \mathrm{H}_{31} \mathrm{ClO}$ & 298.90 & 0.07 & Chlorinated aliphatic ketone \\
\hline 26.779 & 4,4',6,6'-Tetra-tert-butyl-2,2'-biphenyldiol & $\mathrm{C}_{28} \mathrm{H}_{42} \mathrm{O}_{2}$ & 410.64 & 0.05 & Biphenolic compound \\
\hline 26.898 & $\begin{array}{l}\text { 2-Butyl-5-methyl-3-(2-methylprop-2-enyl) } \\
\text { cyclohexanone }\end{array}$ & $\mathrm{C}_{15} \mathrm{H}_{26} \mathrm{O}$ & 222.37 & 0.06 & Cyclic ketone \\
\hline 27.251 & 9-Octadecenoic acid methyl ester & $\mathrm{C}_{9} \mathrm{H}_{36} \mathrm{O}_{2}$ & 296.50 & 0.05 & Aliphatic ester \\
\hline 27.348 & (Z,Z)-6,9-cis-3,4-epoxynonadecadiene & $\mathrm{C}_{19} \mathrm{H}_{34} \mathrm{O}$ & 278.48 & 0.11 & Aliphatic alkene \\
\hline 27.480 & 1-Docosene & $\mathrm{C}_{22} \mathrm{H}_{44}$ & 308.59 & 0.12 & Aliphatic alkene \\
\hline 27.841 & 1-(2,2-Dimethylcyclopentyl) ethanone & $\mathrm{C}_{9} \mathrm{H}_{16} \mathrm{O}$ & 140.23 & 0.06 & Cyclic ketone \\
\hline 27.972 & Heneicosanoic acid & $\mathrm{C}_{21} \mathrm{H}_{42} \mathrm{O}_{2}$ & 326.57 & 0.07 & Fatty acid \\
\hline 28.314 & 7,10-Hexadecadienoic acid & $\mathrm{C}_{16} \mathrm{H}_{28} \mathrm{O}_{2}$ & 252.40 & 0.10 & Fatty acid \\
\hline 29.158 & 9-Heptadecanol & $\mathrm{C}_{17} \mathrm{H}_{36} \mathrm{O}$ & 256.47 & 0.02 & Aliphatic hydroxyl compound \\
\hline 29.463 & Docosanoic acid & $\mathrm{C}_{22} \mathrm{H}_{44} \mathrm{O}_{2}$ & 340.59 & 0.97 & Fatty acid \\
\hline 29.531 & 1,2-Benzenedicarboxylic acid & $\mathrm{C}_{8} \mathrm{H}_{6} \mathrm{O}_{4}$ & 166.13 & 0.40 & Aromatic acid \\
\hline 29.758 & 9,11-Octadecadienoic acid & $\mathrm{C}_{18} \mathrm{H}_{32} \mathrm{O}_{2}$ & 280.45 & 0.04 & Fatty acid \\
\hline 29.831 & 9-Octadecenoic acid & $\mathrm{C}_{18} \mathrm{H}_{34} \mathrm{O}_{2}$ & 282.47 & 0.04 & Aliphatic acid \\
\hline 30.418 & 1-Hexadecanol & $\mathrm{C}_{16} \mathrm{H}_{34} \mathrm{O}$ & 242.45 & 0.10 & Aliphatic hydroxyl compound \\
\hline 30.492 & Octadecane & $\mathrm{C}_{18} \mathrm{H}_{38}$ & 254.50 & 0.03 & Aliphatic alkane \\
\hline 30.915 & Tricosanoic acid & $\mathrm{C}_{23} \mathrm{H}_{46} \mathrm{O}_{2}$ & 354.62 & 0.10 & Aliphatic acid \\
\hline 31.905 & Pentatriacontane & $\mathrm{C}_{35} \mathrm{H}_{72}$ & 492.96 & 0.04 & Aliphatic alkane \\
\hline 32.342 & Tetracosanoic acid & $\mathrm{C}_{24} \mathrm{H}_{48} \mathrm{O}_{2}$ & 368.65 & 0.22 & Fatty acid \\
\hline 33.018 & Geranylgeraniol & $\mathrm{C}_{20} \mathrm{H}_{34} \mathrm{O}$ & 290.49 & 0.08 & Aliphatic hydroxyl compound \\
\hline 33.256 & 1-Heptacosanol & $\mathrm{C}_{27} \mathrm{H}_{56} \mathrm{O}$ & 396.74 & 0.08 & Aliphatic hydroxyl compound \\
\hline 33.516 & Squalene & $\mathrm{C}_{30} \mathrm{H}_{50}$ & 410.73 & 0.09 & Aliphatic alkane \\
\hline 33.767 & Pentacosanoic acid methyl ester & $\mathrm{C}_{26} \mathrm{H}_{52} \mathrm{O}_{2}$ & 396.70 & 0.06 & Aliphatic ester \\
\hline 34.843 & Heptacosane & $\mathrm{C}_{27} \mathrm{H}_{56}$ & 380.75 & 0.04 & Aliphatic alkane \\
\hline
\end{tabular}

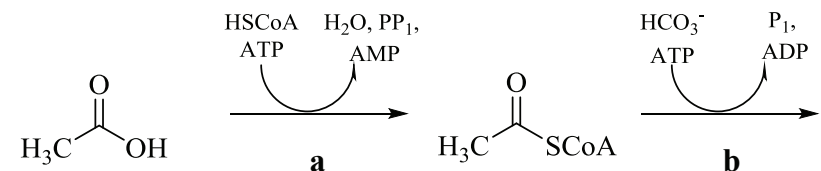

A
B

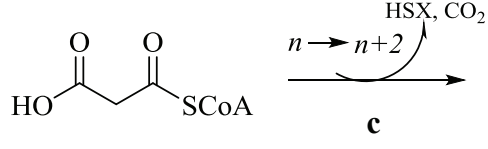

C<smiles>[Y9]C(=O)CC(C)=O</smiles>

D

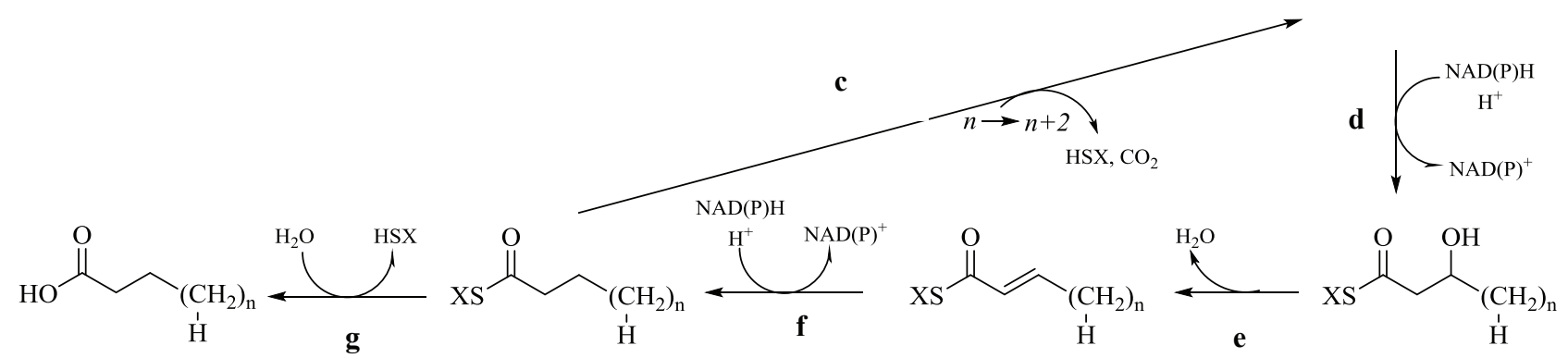

E

Fig. 2: Biosynthetic pathway of fatty acid

A: acetic acid; B: acetyl Co-A; C: malonyl Co-A; D: malonyl Co-A derivative; E: fatty acid. (a) Acetyl Co-A synthase; (b) acetyl Co-A carboxylase; (c) ketoacyl synthase and acyltransferase; (d) ketoacyl reductase; (e) hydroxyacyl dehydratase; (f) enoyl reductase; (g) thioesterase 


\begin{tabular}{|c|c|c|c|c|c|}
\hline \multirow{2}{*}{ COMPOUND } & \multicolumn{4}{|c|}{ Inhibition (\%)* } & \multirow{2}{*}{$I C_{50}$ values $(\mu \mathrm{g} / \mathrm{ml})$} \\
\hline & $25 \mu \mathrm{g} / \mathrm{ml}$ & $50 \mu \mathrm{g} / \mathrm{ml}$ & $75 \mu \mathrm{g} / \mathrm{ml}$ & $100 \mu \mathrm{g} / \mathrm{ml}$ & \\
\hline TNEE & $44.94 \pm 6.40$ & $58.02 \pm 5.06$ & $65.27 \pm 4.65$ & $72.43 \pm 5.38$ & 34.5 \\
\hline Acarbose & $46.11 \pm 4.74$ & $68.25 \pm 6.47$ & $76.06 \pm 5.78$ & $85.79 \pm 5.24$ & 29.5 \\
\hline
\end{tabular}

TNEE is Taxithelium napalense ethanol extract *Mean \pm SD values $(n=3)$

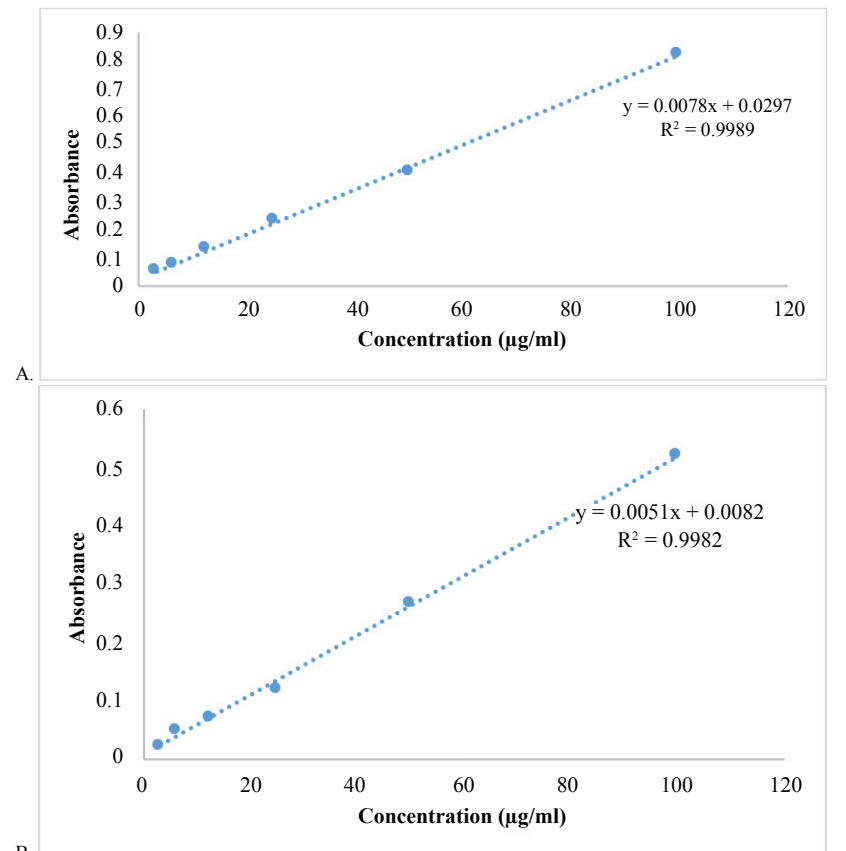

B.

Fig. 3: Standard quercetin and standard gallic acid curves (A) Total flavonoid content of standard quercetin and (B) total phenolic content of standard gallic acid, $R^{2}, n=3$

enzymes (acyl-CoA synthase, acyl-CoA carboxylase, acyltransferase, ketoacyl synthase, ketoacyl reductase, hydroxyacyl dehydratase, enoyl reductase, and thioesterase) and acyl carrier protein) was initiated with acetic acid, CoA, and ATP by using acyl-CoA synthase as catalyst to make acetyl-CoA (fig. 2). By using another ATP and bicarbonate ion catalyzed by acylCoA carboxylase, which yields malonyl-CoA (fig. 2). The obtained malonyl-CoA was added to an acyl chain by catalysis with ketoacyl synthase and acyltransferase, which were usually activated with acyl carrier protein, to make an acyl chain two methylene groups longer (fig. 2). Additionally, reduction, dehydration, and reduction with ketoacyl synthase, hydroxyacyl dehydratase, and enoyl reductase catalysis, respectively, leads to a saturated and unhydroxylated acyl chain activated with acyl carrier protein (fig. 2). If the chain is of appropriate length, it was attacked by thioesterase to release acyl carrier protein, yielding the finished fatty acid (fig. 2). The various fatty acids derived by this pathway was subjected to further reduction, dehydration, and reduction reactions in the cells to yield respective derivatives namely aliphatic aldehydes, aliphatic hydroxyl, aliphatic ketones and aliphatic esters.

The results of total flavonoid content ${ }^{[7]}$ was expressed in terms of $\mathrm{mg}$ of $\mathrm{Q} / \mathrm{g}$ of extract by using standard calibration line Eqn., $y=0.0078 x+0.0297 \mathrm{R}^{2}=0.9989$ (fig. 3A), similarly, the total phenolic content were expressed in terms of $\mathrm{mg}$ of $\mathrm{GA} / \mathrm{g}$ of extract by using standard calibration line Eqn., $\mathrm{y}=0.0051 \mathrm{x}+0.0082$ $\mathrm{R}^{2}=0.9982 \quad$ (fig. 3B). The ethanol extract of T. nepalense contained more total phenolic content than total flavonoid content. The total phenolic content ${ }^{[7]}$ was found to be $229.73 \pm 3.07 \mathrm{mg} \mathrm{GA} / \mathrm{g}$, whereas the total flavonoid content was $101.43 \pm 0.38 \mathrm{mg} \mathrm{Q} / \mathrm{g}$. In addition, the GC-MS analysis also depicted the presence of higher amounts of phenolic compounds in ethanol extract of $T$. nepalense.

The in vitro antidiabetic activity was assessed by $\alpha$-glucosidase inhibitory assay ${ }^{[8]}$ using acarbose as standard and $p$-nitrophenyl- $\alpha$-D-glucopyranoside as a substrate. From the inhibitory assay, it was estimated that the ethanol extract of $T$. nepalense exhibited significant inhibition of $\alpha$-glucosidase enzyme with $\mathrm{IC}_{50}$ values of $34.5 \mu \mathrm{g} / \mathrm{ml}$, whereas acarbose with $29.5 \mu \mathrm{g} / \mathrm{ml}$ (Table 2). The results of $\alpha$-glucosidase inhibitory assay proved the antidiabetic potentiality of T. nepalense.

To conclude, this is the first report on chemical components from stressed moss $T$. nepalense. This study confirmed the presence of various compounds in the moss T. nepalense and also justified the use of this moss as a remedy to diabetes in traditional medicine. This research helped to predict the active metabolites present in the $T$. nepalense, in addition, it also helped in establishing the chemical composition of this moss as well. From these results, it could be concluded that T. nepalense contained various bioactive metabolites. Additionally, the ethanol extract has more total phenolic content than total flavonoid content. However, the isolation of individual secondary metabolites and investigating the biological activity possessed by these would give impetus for further research on the antidiabetic potential of this plant. 


\section{Acknowledgements:}

The authors thank the authorities of AU College of Pharmaceutical Sciences, Andhra University, Visakhapatnam, Andhra Pradesh, India for providing the necessary facilities to complete present work. The authors also thank Dr. Ankita Srivastava, CSIRNational Botanical Research Institute (NBRI), Lucknow for identifying the moss species collected.

\section{Conflicts of interest:}

The authors declare that there is no conflict of interest.

\section{REFERENCES}

1. Sastry GV, Bharadwaj VT. Occurrences of mosses in Indian mangrove forests. J Integr Sci 2018;1:1-6.

2. Decker EL, Reski R. Moss bioreactors producing improved biopharmaceuticals. Curr Opin Biotechnol 2007;18:393-8.

3. Kang HR, Lee D, Eom HJ, Lee SR, Lee KR, Kang KS, et al. Identification and mechanism of action of renoprotective constituents from peat moss Sphagnum palustre in cisplatininduced nephrotoxicity. J Funct Foods 2016;20:358-68.

4. Eom HJ, Park YJ, Kang HR, Kim HR, Bang IJ, Park HB, et al. Inhibitory effect of Sphagnum palustre extract and its bioactive compounds on aromatase activity. Bangladesh J Pharmacol 2016;11:661-5.

5. Ramsay HP, Schofield WB, Tan BC. The genus Taxithelium (Bryopsida, Sematophyllaceae) in Australia. Aust Syst Bot 2002;15:583-96.

6. Tatipamula VB, Killari KN, Ketha A, Vedula GS. Taxithelium napalense acts against free radicals and diabetes mellitus. Bangladesh J Pharmacol 2017;12:197-203.

7. Tatipamula VB, Vedula GS, Rathod BB, Shetty PR, Sastry AVS. Study of phytochemical analysis, total flavonoid and phenolic content, antimicrobial properties and chemical constituents of two manglicolous lichens extracts. Planta Activa 2018;2018:129-34.

8. Tatipamula VB, Kolli MK, Lagu SB, Paidi KR, Reddy RP, Yejella RP. Novel indolizine derivatives lowers blood glucose levels in Streptozotocin-induced diabetic rats: A histopathological approach. Pharmacol Rep 2019;71(2):23342. 